\title{
Meta
}

Journal des traducteurs

Translators' Journal

\section{Vitale, Geoffrey (1993): Words in Sympathy, Paris, Dunod \\ Vitale, Geoffrey (1995): Words in Context, Paris, Dunod}

\section{Daniel Slote}

Volume 42, numéro 3, septembre 1997

L’interprétation en langues des signes

URI : https://id.erudit.org/iderudit/004180ar

DOI : https://doi.org/10.7202/004180ar

Aller au sommaire du numéro

Éditeur(s)

Les Presses de l'Université de Montréal

ISSN

0026-0452 (imprimé)

1492-1421 (numérique)

Découvrir la revue

Citer ce compte rendu

Slote, D. (1997). Compte rendu de [Vitale, Geoffrey (1993): Words in Sympathy, Paris, Dunod / Vitale, Geoffrey (1995): Words in Context, Paris, Dunod]. Meta, 42(3), 593-595. https://doi.org/10.7202/004180ar

Ce document est protégé par la loi sur le droit d'auteur. L'utilisation des services d'Érudit (y compris la reproduction) est assujettie à sa politique d'utilisation que vous pouvez consulter en ligne.

https://apropos.erudit.org/fr/usagers/politique-dutilisation/
Cet article est diffusé et préservé par Érudit.

Érudit est un consortium interuniversitaire sans but lucratif composé de l’Université de Montréal, l'Université Laval et l'Université du Québec à Montréal. Il a pour mission la promotion et la valorisation de la recherche. https://www.erudit.org/fr/ 
VITALE, Geoffrey (1993): Words in Sympathy, Paris, Dunod.

- VITALE, Geoffrey (1995): Words in Context, Paris, Dunod.

The two books under review, Words in Sympathy and the new, revised edition of Words in Context, were published respectively in 1993 and 1995, by Dunod, Paris. Even though the first book was published two years before Words in Context, they are companion volumes and it is fitting they both should be reviewed at the same time. They are both intended for university-level students in ESL and translation, and the original edition of Words in Context, written by Geoffrey Vitale and reviewed by Jean Darbelnet, who also contributed the exercises, has been in print without a break since 1972.

Both books deal with what Geoffrey Vitale terms "parasynonyms." His approach is to suggest that synonyms as such do not exist, that indeed when two words become dangerously similar in interpretation, one of them will tend to drop into disuse, or be preempted for a narrower semantic use. Obvious examples in contemporary English are the restricted use of gay and queer, whose original meanings have been perfectly well covered by a variety of overlapping terms such as happy, merry, light-hearted, strange, peculiar, curious, etc. But of course language has been evolving along these lines for a very long time: we merely need to refer to the differentiations that occurred between terms that came into English from Latin, French and Norman French and that either eliminated the Old English synonym ('book hoard' being replaced by 'library' for instance) or carved out quite different semantic fields for each item (vide 'benediction' (L), 'benison' (OF) and 'blessing' (OE)).

The author defends what is left, still a rich brew, arguing that what John Trusler, the 18th century synonymist called 'The Difference between Words Esteemed Synonymous,' is something that goes beyond the scope of the standard dictionary,as synonyms, take on very specific, even dissimilar nuances once placed in context. He gives examples of these lacunae by discussing listings from a number of dictionaries, as for instance the Shorter Oxford's definition of slothful: "full of sloth; indisposed to exertion; inactive, indolent, lazy, sluggish", pointing out that there is a mighty difference between a "slothful river" and a "sluggish river"; that the stock market may be "sluggish", but is rarely "slothful". Adding to his list, one might suggest that trade unions would thoroughly object to any attempt to assimilate an "inactive" worker to an "idle" one. In similar vein, he takes aim at what he terms "linguistic kiting (one deposit fraudulently switching between two accounts)" as practiced by most dictionaries, including the very contemporary BBC English Dictionary which defines, for example, tepid as "slightly warm" or, in its idiomatic sense, a feeling or reaction that "lacks enthusiasm"; while describing an object that is lukewarm as "only slightly warm" and idiomatically as "not showing much enthusiasm [...] or interest." He terminates with a gleeful swipe at yet another pillar of respectability, Webster's New World which "defines lukewarm as 'barely or moderately warm; said of liquids,' and refers back etymologically to Middle English LUKE, which it translates as 'tepid'. It then turns to TEPID, which it defines as "barely or moderately warm; lukewarm: said of liquids."”

The approach used by Geoffrey Vitale, as a teacher and in this case writer of language manuals, is one of definition, example and context. Words in Sympathy deals with the vocabulary of feelings, sociability and morality.

There are four main chapters each covering a series of areas relevant to the main heading. Chapter 1, THE SENTIENT PERSON, deals with the notions of comfort and discomfort, suffering, weather and temperature, sufficiency and insufficiency. Chapter 2, THE EMOTIONAL things, affection, dislike, and depressions, while the othe good and bad manners, modesty and pride, deceit and disrepute, etc. Each lexical item is carefully defined, a number of codes are used to indicate extended or idiomatic uses of the term, 
and a series of examples is provided to illustrate both the term itself and the nuances between the chosen word and its parasynonyms. The terms are grouped by similarity of meaning. Thus, dispassionate is discussed and compared to and with unimpassioned and passionless, illustrated with separate examples, and the three terms are finally brought together in a complex sentence: He was sentenced to death by the dispassionate judgment of the court, and the unimpassioned administration of the sentence was carried out by a passionless machine, the electric chair. The somewhat contrived nature of such a sentence does, of course, have to be balanced against the effectiveness of the discrimination between the parasynonyms. In most cases, however, the examples are natural enough to be acceptable, and the range of sources or contexts allows for a full grasp of the shades of meaning and usage covered. A slightly longer example, that of PRANCE, clearly illustrates this approach. We should note that when a word appears in capitals in the text, this means it will be found elsewhere under a separate entry, as is the case with MINCE, STRUT and SWAGGER, cited below:

\section{PRANCE (v.i.) [MINCE, STRUT]}

Primarily this describes the half-dancing movement of a horse springing from its hind legs, as for example, in a parade when a horse won't stand still. Otherwise, it is essentially a literary term, used to describe a foppish walk: exaggerated and involving rising on the toes and much movement of elbows and arms. This may be differentiated from STRUT, which supposes elbows and arms are held quite stiffly: The mime pranced into the room, bowing to right and to left, preening himself like a peacock.

Note: STRUT, PRANCE and SWAGGER are masculine attributes. One might occasionally find SWAGGER used for a woman, but this would suppose a particule. A neat differentiation between prance and mince is made by Shakespeare on the one hand, when Hotspur contemptuously refuses to "cry mew in mincing poetry" (I Henry IV) and Emily Dickinson, on the other, who feels that even a racing horse (a "Courser") cannot compare with "a page of prancing poetry" (Poem 1263, c. 1873).

The example above is taken from the new, revised edition of Words in Context, which is half as long again as the 1972 edition and has a completely new series of exercises, along with an answer book. This inclusion of examples of uto the sixteenth century, following a number of requests from the author's readers, has of course meant providing examples or uses which are no longer acceptable in contemporary society, for racial or gender reasons. The author justifies their inclusion on the grounds that he is a descriptive, not a prescriptive linguist and does "not believe one should attempt to exorcize history or excoriate those whose terminology offends our contemporary sensibilities." Then in a very contemporary vein, which will strike a responsive chord in many of us, he ends by affirming that "Linguistic witch-hunting is an ugly custom and it tends to emasculate more than just our language."

This interest in less contemporary lexical items includes a glance at some expressions that are no longer current. For example, in the chapter on Collectives, he notes with regret the disappearance of such colourful descriptors as 'a sloth of bears' and 'a skulk of foxes', together with two delightful but both figuratively and literally obsolete examples from the late fifteenth century: a pontificalyte of prestys and a suprfluyte of nuns. These last two were culled from Brewer's Dictionary of Phrase and Fable: and our author makes no bones about borrowing from secondary sources. He provides a substantial list with both Words in Sympathy and Words in Context.

Words in Context takes a similar approach to that of its companion volume, except that the listing within each sean comparative, and parasynonyms are cross-referenced for easier consultation. The areas covered are those of perception and movement and include light, sound, collectives, texture and consistency, physical appearance, expression and mood, 
and movement. In both volumes, considerable attention is paid to semantic changes in language. For example, in the sections on Virtue and Vice (Words in Sympathy), the author points out that "many attributes which were, a few years ago, applied to the person in all seriousness (e.g. purd to have an ironic connotation today... and the cardinal virtues... require a somewhat different vocabulary in which the stress is on ethical and social behaviour, rather than on the moral qualities underlined by the traditions of the churches." He illustrates this by entries under decent (British usage mainly for someone who has the qualities of honesty and sexual and social stability) and the very American complimentary term, mature, with its overtones of a pro-establishment attitude to both politics and morality.

A significant advantage of Words in Context is the inclusion of the answer book for the exercises. This allows the student to use the manual for self-study. I suspect, however, both volumes will be found most useful as reference books for students in translation and in ESL, allowing them to fine-hone their understanding of the vocabulary they encounter in their readings. A definite drawback is the price, each volume runs to forty dollars plus, but this, apparently, is due to the complexities of lay-out and the various typefaces used, together with the fact that these books are imported from Europe. As reference works, however, their extended shelf-life should justify the cost. 